\title{
Design and optimization of an electrocoagulation reactor for fluoride remediation in underground water sources for human consumption
}

\author{
A. Betancor-Abreu ${ }^{1}$, V.F. Mena ${ }^{1}$, S. González ${ }^{1}$, S. Delgado ${ }^{2}$, R.M. Souto ${ }^{1,3}$, J.J. Santana ${ }^{4}$ \\ ${ }^{1}$ Department of Chemistry, Universidad de La Laguna, P.O. Box 456, E-38200 La Laguna \\ (Tenerife), Spain. \\ ${ }^{2}$ Department of Chemical Engineering and Pharmaceutical Technology, Universidad de La \\ Laguna, P.O. Box 456, E-38200 La Laguna (Tenerife), Spain. \\ ${ }^{3}$ Institute of Materials and Nanotechnology, Universidad de La Laguna, P.O. Box 456, E-38200 \\ La Laguna (Tenerife), Spain. \\ ${ }^{4}$ Department of Process Engineering, Universidad de Las Palmas de Gran Canaria, Campus \\ Universitario de Tafira, E-35017 Las Palmas de Gran Canaria (Gran Canaria), Spain.
}

\begin{abstract}
Fluoride remediation in underground waters of volcanic origin was performed at laboratory scale using an electrocoagulation (EC) technique. The natural waters from certain volcanic springs on the island of Tenerife (Canary Islands, Spain) contain average fluoride concentrations in excess of $7 \mathrm{mg} / \mathrm{L}$. Thus, it is necessary to treat the water for fluoride mitigation below the maximum acceptable concentration of $1.5 \mathrm{mg} / \mathrm{L}$ according to Spanish regulations for drinking water. The design and optimization of a sustainable process was accomplished using a progressive scale-up procedure involving three pilot reactors with different configurations and effective working volumes. A bipolar electrode cell design using aluminum electrodes was used in all cases. The good performance of the process was confirmed by reducing the fluoride concentration from 7.35 to $1.4 \mathrm{mg} / \mathrm{L}$. The following optimized operating conditions were determined for a continuous flow cell system: current density, $10 \mathrm{~mA} / \mathrm{cm}^{2}$; residence time, $10 \mathrm{~min}$; and, half-period of polarity reversal, 1 min. Furthermore, the kinetics of the remediation process can be fitted using the Variable Order Kinetic (VOK) model, with a power relationship between fluoride concentration and residence time in the EC reactor.
\end{abstract}

Keywords: Underground water remediation; Fluoride mitigation; Electrocoagulation technique; Reactor design; Kinetics of the electrocoagulation reaction. 


\section{Introduction}

The nature and the extent of the effects on human health caused by fluoride ions present in drinking water greatly depend on the ion concentration. Although certain beneficial effects occur when these ions are present in rather small amounts, major concern arises from the adverse effects reported in the case of fluoride concentrations higher than a maximum acceptable value [1,2]. According to the World Health Organization (WHO), the optimum concentration of fluoride in drinking water lies within the $0.7-1.5 \mathrm{mg} / \mathrm{L}$ range [3], and values within this interval are typically adopted as the maximum acceptable limit by many countries, including Spain (RD 140/2003) [4,5]. Unfortunately, fluoride concentrations greater than those regarded acceptable by the legislation in force can occur naturally in underground waters from volcanic regions such as the Canary Islands [6,7]. Indeed, fluoride concentrations in excess of $7 \mathrm{mg} / \mathrm{L}$ occur in a large number of underground springs on the most populated island of Tenerife, thus generating a major health issue because groundwater is the main natural source of water supply in this Archipelago [6]. This means that water treatment procedures are necessary to meet the legal requirements for drinking water usage.

Several treatment methods are proposed in the scientific literature for the removal of excess fluoride from natural water for human consumption. These methods can be grouped into three main categories on the basis of their main operating principle; namely, chemical precipitation processes [8,9], adsorption and ion exchange processes [10,11], and membrane-based processes (including reverse osmosis [12,13] and electrodialysis (ED) [14,15]). When adopting a sustainable remediation procedure, in addition to the operating costs, a major factor is the water rejection rate. Large variations in this rate occur among these methods, ranging from ca. 1-2\% for the majority of the proposed methods, though it may reach $20-30 \%$ for electrodialysis procedures, and it can be as high as $40-60 \%$ in the case of reverse osmosis. Since natural water is a scarce and valuable natural resource in the Canary Islands, procedures for water treatment are also aimed at minimizing water losses [16].

Although scarcely employed for fluoride remediation in practical situations, electrocoagulation (EC) techniques have been proposed for the treatment of urban [17-19] and industrial [20-24] wastewaters, and even for the treatment of water for human consumption $[25,26]$. In comparison with the other techniques mentioned above, the EC technique exhibits high fluoride removal efficiencies, easy operation at a relatively low cost, very low water rejection, and 
the possibility of implementing a completely automated system [27,28]. The kinetics of fluoride removal in an EC process using aluminum electrodes depends on various factors. Mameri et al. established that the rate determining process is the release of $\mathrm{Al}(\mathrm{III})$ for current densities smaller than $20 \mathrm{~mA} / \mathrm{cm}^{2}$ [29]. Under these conditions, the reaction rate is instantaneous and approaches a pseudo-first-order kinetics with respect to fluoride concentration [29,30]:

$$
\frac{\left[\mathrm{F}^{-}\right]_{\mathrm{t}}}{\left[\mathrm{F}^{-}\right]_{\mathrm{i}}}=e^{-K_{1} \cdot t}
$$

where $\left[\mathrm{F}^{-}\right]_{\mathrm{t}}$ and $\left[\mathrm{F}^{-}\right]_{\mathrm{i}}$ are the fluoride concentrations $(\mathrm{mol} / \mathrm{L})$ for a certain time $t$ and for the initial instant, respectively; $K_{1}$ is the first-order velocity constant $\left(\mathrm{min}^{-1}\right)$; and $t$, the reaction time (min). An improvement in this model was proposed by Hu et al. with the Variable Order Kinetic (VOK) model [31], which is described by equation (2):

$$
\frac{-d\left[\mathrm{~F}^{-}\right]}{d t}=\varepsilon_{A l} \cdot \varepsilon_{C} \frac{n \cdot I}{Z \cdot F \cdot V} \cdot \frac{\Gamma_{\max } \cdot k \cdot\left[\mathrm{F}^{-}\right]}{1+k \cdot\left[\mathrm{F}^{-}\right]}
$$

where $\varepsilon_{\mathrm{Al}}$ is the yield of hydro-fluoro-aluminum formation (\%), $\varepsilon_{C}$ the current efficiency, $n$ the cell number, $I$ the current (A), $Z$ the valence ( $Z=3$ for aluminum), $F$ the Faraday constant $(96,500 \mathrm{C})$, $V$ the working volume (L) of water in the reactor, $\Gamma_{\max }$ the maximum amount of fluorides removed per mole of $\mathrm{Al}(\mathrm{III})$ at a given $\mathrm{pH}$, and $k$ the Langmuir constant $(\mathrm{L} / \mathrm{mol})$. The terms in equation (2) depend on various factors that influence the electrocoagulation process, namely the nature and concentration of pollutants [32], $\mathrm{pH}$ [33], the nature and distance between the electrodes [27], and the applied charge density [30]. It should be noted that most studies and reactor designs performed on a laboratory scale that are available in the scientific literature were tested using synthetic waters of fixed composition, and consisted of analyzing the influence of each operating factor on fluoride mitigation in turn. However, natural waters from volcanic springs, such as those occurring in the Canary Islands, exhibit large and complex seasonal variations in their composition, and the operating conditions of these reactors would require frequent adjustments.

On the northern side of Tenerife, particularly in the zone including La Guancha, Icod de los Vinos and San Juan de la Rambla municipalities (Figure 1), fluoride content within the range of 5.78 - $8.98 \mathrm{mg} / \mathrm{L}$ has been recorded [34]. It is precisely in this geographical area where the main water springs are located that supply drinking water to a large proportion of the island's population. This imposes the need for water treatment in order to reduce the fluoride content to acceptable values according to the legislation for human consumption. At present, this is accomplished using 
reverse osmosis procedures, although at the cost of high water rejection rates, and indeed rejecting natural water from those springs presenting the highest fluoride loads. In this work, we investigated the suitability of the electrocoagulation technique for the treatment of natural waters from volcanic springs with the aim of obtaining water products with a fluoride concentration within the range established by the regulations currently in force.
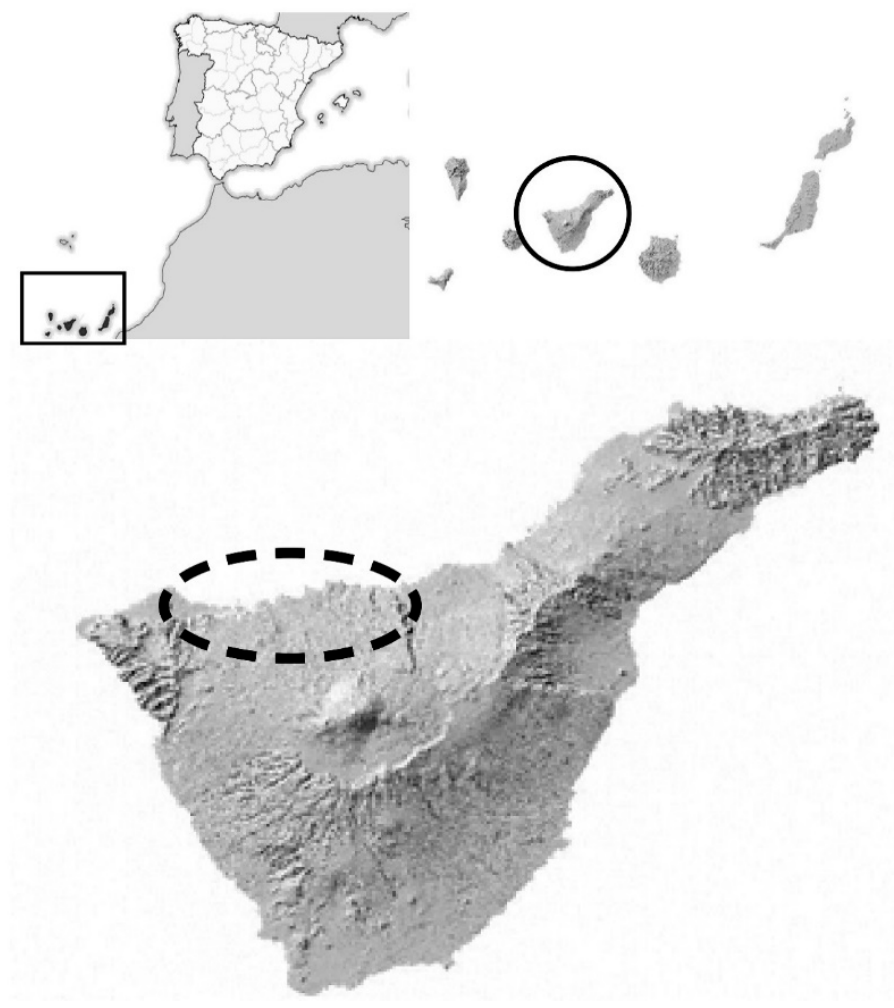

Figure 1. Geographical origin of the natural underground water used in this study.

\section{Methods and materials}

\subsection{Water}

The water used in the study came directly from the Barranco de Vergara Gallery located in La Guancha (Tenerife, Canary Islands). Water was periodically collected without prior treatment, and stored in non-absorbent PVC containers for transfer to the laboratory. The characteristic parameters of both untreated and product waters were determined at regular times, namely fluoride content as well as $\mathrm{Ca}^{2+}, \mathrm{Mg}^{2+}, \mathrm{K}^{+}, \mathrm{Na}^{+}, \mathrm{CO}_{3}^{2-}, \mathrm{HCO}_{3}^{-}, \mathrm{SO}_{4}^{2-}, \mathrm{Cl}^{-}, \mathrm{NO}_{3}^{-}, \mathrm{NO}_{2}^{-}$, and $\mathrm{PO}_{4}^{3-}, \mathrm{pH}$ and conductivity. Typical physicochemical characteristics of the raw water are listed in Table 1. It must be noted that its natural $\mathrm{pH}$ was 7.8 , whereas the fluoride concentration was $7.35 \mathrm{mg} / \mathrm{L}$. 
Table 1. Analysis of the raw water from Galería Vergara (Tenerife, Spain).

\begin{tabular}{cc}
\hline Parameter & Raw water \\
\hline $\mathrm{pH}$ & 7.8 \\
Conductivity $(\mu \mathrm{S} / \mathrm{cm})$ & 2320 \\
$\mathrm{~F}^{-}(\mathrm{mg} / \mathrm{L})$ & 7.35 \\
$\mathrm{Ca}^{2+}(\mathrm{mg} / \mathrm{L})$ & 36.7 \\
$\mathrm{Mg}^{2+}(\mathrm{mg} / \mathrm{L})$ & 76.0 \\
$\mathrm{~K}^{+}(\mathrm{mg} / \mathrm{L})$ & 77.7 \\
$\mathrm{Na}^{+}(\mathrm{mg} / \mathrm{L})$ & 467 \\
$\mathrm{CO}_{3}^{2-}(\mathrm{mg} / \mathrm{L})$ & $<0.25$ \\
$\mathrm{HCO}_{3}^{-}(\mathrm{mg} / \mathrm{L})$ & 1614 \\
$\mathrm{SO}_{4}^{2-}(\mathrm{mg} / \mathrm{L})$ & 90 \\
$\mathrm{Cl}^{-}(\mathrm{mg} / \mathrm{L})$ & 27 \\
$\mathrm{NO}_{3}^{-}(\mathrm{mg} / \mathrm{L})$ & 1.7 \\
$\mathrm{NO}_{2}^{-}(\mathrm{mg} / \mathrm{L})$ & $<0.1$ \\
$\mathrm{PO}_{4}^{3-}(\mathrm{mg} / \mathrm{L})$ & 0.8 \\
\hline
\end{tabular}

Given that $\mathrm{pH}$ and fluoride concentration are the most important parameters controlling the adequacy of electrocoagulation operation for fluoride mitigation, the performance of the EC experiments was dynamically controlled on the basis of these two parameters using a potentiometric technique. The water $\mathrm{pH}$ was monitored with a model $691 \mathrm{pH}$ Meter (Metrohm, Herisau, Switzerland) using a pH probe, which contained an internal reference electrode and a temperature sensor. Likewise, the concentration of fluoride ions was determined using an ionselective electrode connected to a model $827 \mathrm{pH}$ lab instrument supplied by Metrohm as well. In 
this case, an $\mathrm{Ag} / \mathrm{AgCl}$ electrode in saturated $\mathrm{KCl}$ solution was employed as the reference electrode. The activity of the other ionic species present in the water sample was cancelled by adding a buffer solution of $\mathrm{pH} 5.5$ as indicated by the manufacturer. The operation of the fluoride ion-selective electrode was calibrated using solutions of known fluoride concentration in the $0.5-15 \mathrm{mg} / \mathrm{L}$ range.

The percentage of fluoride removal was determined using equation (3):

$$
\operatorname{Removal}(\%)=\frac{\left[\mathrm{F}^{-}\right]_{\mathrm{i}}-\left[\mathrm{F}^{-}\right]_{\mathrm{f}}}{\left[\mathrm{F}^{-}\right]_{\mathrm{i}}} \cdot 100
$$

where $\left[\mathrm{F}^{-}\right]_{\mathrm{i}}$ and $\left[\mathrm{F}^{-}\right]_{\mathrm{f}}$ are the initial and the final concentration of fluoride ions in solution, respectively.

\subsection{Experimental setup}

Aluminum plates with dimensions $50 \mathrm{~mm} \times 120 \mathrm{~mm} \times 2 \mathrm{~mm}$ were used as electrodes in the electrocoagulation process. The electrodes, once cut to their final dimensions, were subjected to a cleaning and conditioning process according to ASTM G1-03(2017) standard [35]. The electrodes were placed in a parallel arrangement in order to facilitate the symmetry of the current lines in the reactor and minimizing geometrical hindrances to water flow apart from those produced by the surface of the electrodes. Three reactors of different capacities were designed for scaling up the EC process. The simplest arrangement was a 2-electrode batch reactor (R1) of $147 \mathrm{~mL}$ working volume, the separation between the aluminum electrodes was $5 \mathrm{~mm}$, and the total working electrode area amounted to $58 \mathrm{~cm}^{2}$, while keeping a surface/volume ratio close to 0.4 . The polarity of the electrodes was periodically changed so that both electrodes would operate either as cathode or anode for the same length of time, thus being consumed to almost the same extent throughout the experiments. Magnetic stirring ensured mixing in the system. Figure 2A shows a sketch depicting the electrode arrangement and connections to the measuring control unit for operation as monopolar batch reactor. Reactor R1 thus served to validate the feasibility of the EC technique for the mitigation of fluorides in underground waters destined for human consumption. Next, a multi-electrode batch reactor consisting of a cylindrical vessel with an effective volume of $368 \mathrm{~mL}$ capacity (R2) was considered. Six aluminum plates with a total active area of $147 \mathrm{~cm}^{2}$ were employed, although still maintaining a surface/volume ratio close to 0.4 . The electrodes were placed in the reactor spaced $5 \mathrm{~mm}$ apart, and magnetic stirring was performed at the bottom of the 
reactor. Electrode arrangement and connections to ensure bipolar operation under batch conditions are sketched in Figure 2B.

Finally, a larger reactor of $2000 \mathrm{~mL}$ (R3) was employed under both batch and continuous flow operation conditions. In this case, 14 aluminum electrodes were arranged with $5 \mathrm{~mm}$ separation between the electrodes, and they were placed perpendicular to the main direction of water flow, thus effectively operating under cross flow conditions. The total electrode surface was $840 \mathrm{~cm}^{2}$. Stirring conditions were imposed using a recirculation pump immersed inside the reactor (see Figure 3) in order to ensure a complete mixing regime. Under continuous flow operation, the product water was evacuated from the upper level of the reactor (drain) into a flocculation tank, and the raw water was also introduced from just above the water level in the reactor although in the opposite corner from the drain.

A)

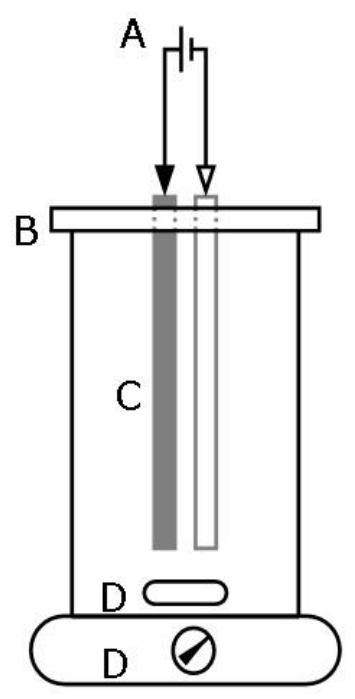

B)

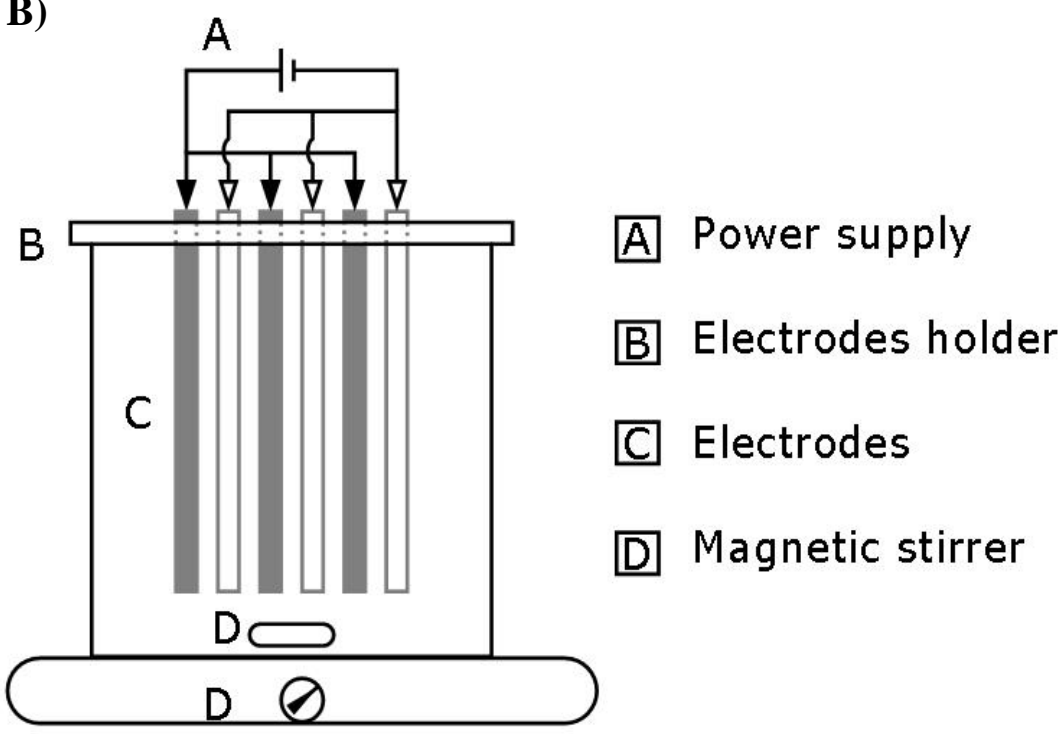

Figure 2. Sketches of the two bipolar cell arrangements employed for batch tests: A) R1, with volume $147 \mathrm{~mL}$; and B) R2, with volume $368 \mathrm{~mL}$.

Current supply and voltage monitoring in the EC reactors was performed using a QPX1200SP power source (AIM-TTI) operated under computer control. Main specifications of the power source are a maximum output voltage of $60 \mathrm{~V}$ and maximum output current of $50 \mathrm{~A}$, both values subject to a maximum power demand of $1200 \mathrm{~W}$. The entire device was controlled 
through a PIPO computer equipped with Windows ${ }^{\circledR}$ and its own control software interface. Polarity changes could be performed at fixed times ranging from $1 \mathrm{~s}$ to $48 \mathrm{~h}$.

All the measurements made in this work have been performed at least in duplicate to ensure reproducibility.
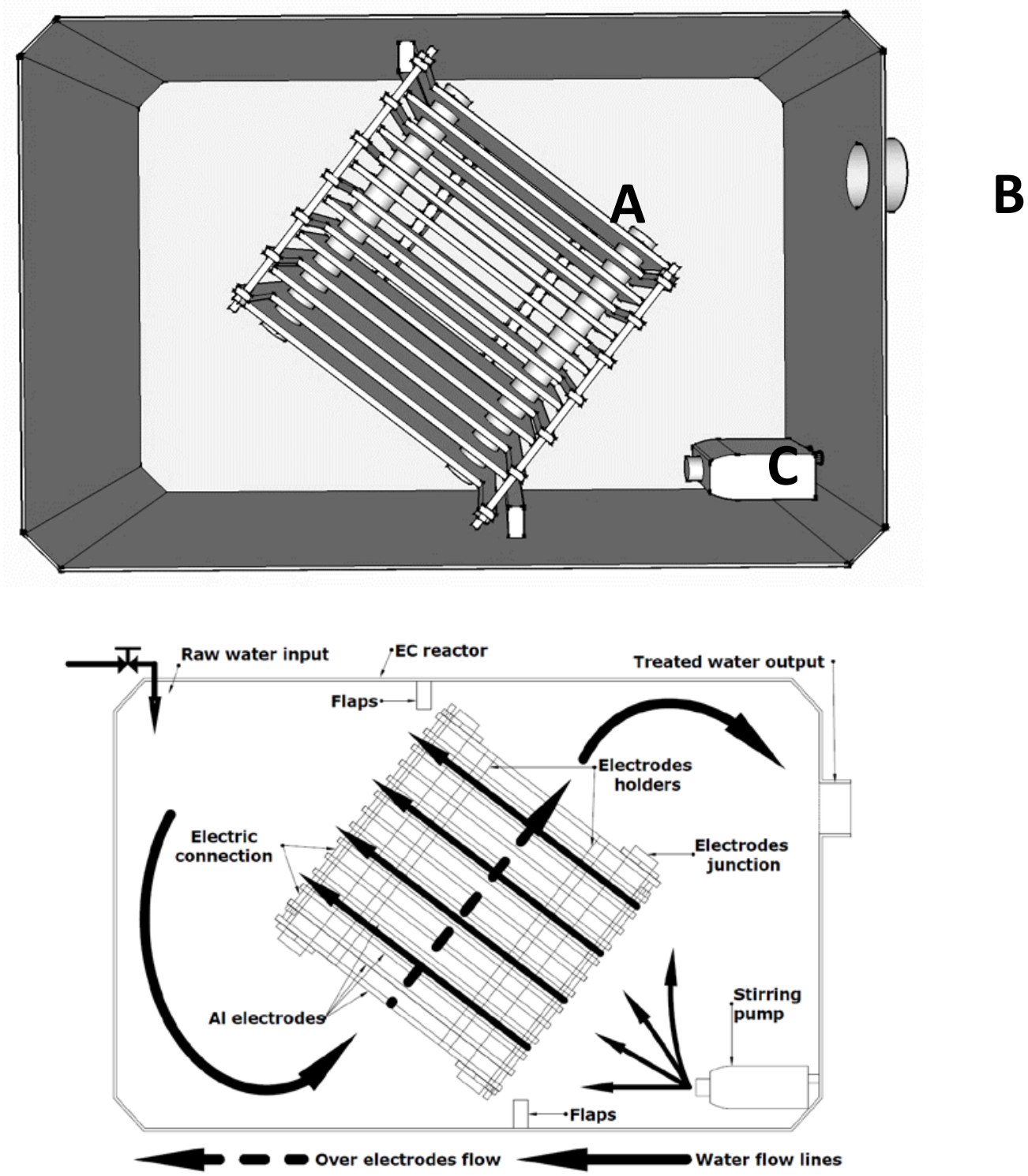

Figure 3. Sketches of the bipolar cell arrangement employed for continuous flow experiments (R3; volume, $2000 \mathrm{~mL}$; total electrode effective area, $840 \mathrm{~cm}^{2}$; S/V ratio, 0.4; separation between electrodes: $5 \mathrm{~mm}$ ). A) Electrode holder; B) drain for the product water; C) stirring pump. 


\subsection{Sludge characterization}

The sludge produced in the EC process was separated by atmospheric filtration from the treated water in the flocculation tank, and it was allowed to dry during $24 \mathrm{~h}$ at room temperature. The resulting powder was ground and its chemical composition was analyzed by XRD (PANalytical X'Pert PRO, Malvern Panalytical, Almelo, The Netherlands). Zeta potential analysis was performed using Zetasizer Nano ZS (Malvern Panalytical, Malvern, UK).

\section{Results and discussion}

The technical feasibility of the electrocoagulation technique at laboratory scale was tested using a sequence of three reactors of different working volumes to scale-up the methodology with the aim of attaining a continuous operation using natural waters from water galleries presenting high fluoride concentrations. For the sake of comparative purposes, the operation parameters considered in the experiments are listed in Table 2.

Table 2. Operation parameters used in the EC reactors used in this study.

\begin{tabular}{lcc}
\multicolumn{1}{c}{ Parameter } & \multicolumn{2}{c}{ Operational values } \\
& Fixed & Variable \\
\hline Current density $\left(\mathrm{mA} / \mathrm{cm}^{2}\right)$ & - & $3 ; 5 ; 7.5 ; 10$ \\
$S / V$ ratio $(\mathrm{cm})$ & 0.4 & - \\
Separation between electrodes $(\mathrm{cm})$ & 0.5 & - \\
Operation time (min) & - & $5 ; 10 ; 15$ \\
Polarity half-period (min) & - & $0.5 ; 1 ; 2$ \\
\hline
\end{tabular}

The performance of the process was optimized by monitoring the quality of the treated water. In addition, an estimate of the operation costs for the process was made taking into account both electrode weight loss and electricity consumption. Accordingly, operating costs were determined using: 


$$
\text { Operation Cost }=a \cdot E C_{\text {Electrode }}+b \cdot E C_{\text {Energy }}
$$

where $E C$ Electrode is the weight of aluminum dissolved per unit volume of treated water $\left((\mathrm{kg} \mathrm{Al}) / \mathrm{m}^{3}\right)$, $E C_{\text {Energy }}$ the electricity consumed per unit volume of treated water $\left(\mathrm{kWh} / \mathrm{m}^{3}\right), a$ and $b$ are coefficients representing the typical costs of these parameters for the Spanish market in 2018 (e.g., $a=1.720 € /(\mathrm{kg} \mathrm{Al}), b=0.117 € / \mathrm{kWh})$.

Several tests have been carried out in which the effect exerted by the variation of the current density, the $\mathrm{pH}$, the duration of polarity change to the electrodes (half-period), and the residence time of the sample in the reactor have been evaluated. These tests were carried out in a discontinuous regime and under steady state operation.

Table 3 shows the variability ranges of the parameters controlled and modified in the different optimization tests. These parameters have been chosen due to their relevance in the process of fluoride removal using the electrocoagulation technique.

\subsection{Reactor of $147 \mathrm{~mL}$}

The simplest arrangement was a 2-electrode batch reactor (R1) with $147 \mathrm{~mL}$ working volume, which was designed to replicate the best systems described in the literature for this process until now. Accordingly, the separation between the aluminum electrodes was set at $5 \mathrm{~mm}$, and the total working electrode area amounted to $58 \mathrm{~cm}^{2}$ [36-38], while keeping a surface/volume ratio close to 0.4 [39].

The results obtained using the $147 \mathrm{~mL}$ capacity reactor are presented in Table 3 and Figure 4 for the three half-periods of polarity change considered in this work. In all cases, fluoride elimination in excess of $80 \%$ initial ion concentration was obtained. This is a threshold level sufficient to achieve fluoride content acceptable for human usage in the product water. In experiments where polarization periods were 0.5 and $1 \mathrm{~min}$, such condition was only achieved by using the highest current density $\left(10 \mathrm{~mA} / \mathrm{cm}^{2}\right)$ and with a residence time of $15 \mathrm{~min}$. By contrast, occurrences of this threshold level happened at the lower current densities of 5 and $7.5 \mathrm{~mA} / \mathrm{cm}^{2}$ in the tests performed with a period of 2 min for the polarity change of the electrodes.

Table 3. Final concentration $\left[\mathrm{F}^{-}\right]$and final $\mathrm{pH}$ depending on the operating parameters for the three reactors tested in batch operation. $\mathrm{R} 1=147 \mathrm{~mL}$ reactor; $\mathrm{R} 2=365 \mathrm{~mL}$ reactor; $\mathrm{R} 3=2000 \mathrm{~mL}$ reactor. 


\begin{tabular}{|c|c|c|c|c|c|c|c|c|}
\hline \multirow{3}{*}{ Reactor } & \multirow{3}{*}{$\begin{array}{c}\text { Current } \\
\text { density } \\
\left(\mathrm{mA} / \mathbf{c m}^{2}\right)\end{array}$} & \multirow{3}{*}{$\begin{array}{c}\text { Polarity half-period } \\
\text { (min) }\end{array}$} & \multicolumn{6}{|c|}{ Time of residence $(\mathrm{min})$} \\
\hline & & & 5 & 10 & 15 & 5 & 10 & 15 \\
\hline & & & & {$\left[\mathrm{F}^{-}\right]_{\mathrm{f}}$} & & & $\mathrm{pH}_{\mathrm{f}}$ & \\
\hline \multirow{12}{*}{ R1 } & \multirow{3}{*}{3} & 0.5 & 3.26 & 2.95 & 2.04 & 8.75 & 8.80 & 7.95 \\
\hline & & 1 & 5.34 & 4.03 & 3.58 & 8.75 & 8.80 & 7.95 \\
\hline & & 2 & 4.06 & 4.02 & 3.56 & 8.25 & 8.20 & 8.65 \\
\hline & \multirow{3}{*}{5} & 0.5 & 3.58 & 2.70 & 2.04 & 8.00 & 8.20 & 8.25 \\
\hline & & 1 & 2.93 & 1.81 & 1.89 & 7.90 & 7.98 & 8.05 \\
\hline & & 2 & 2.81 & 1.54 & 1.54 & 8.45 & 8.60 & 8.00 \\
\hline & \multirow{3}{*}{7.5} & 0.5 & 3.30 & 2.04 & 1.81 & 8.02 & 8.15 & 8.20 \\
\hline & & 1 & 2.81 & 1.54 & 1.54 & 8.50 & 8.00 & 8.10 \\
\hline & & 2 & 3.05 & 1.81 & 1.54 & 8.50 & 8.00 & 8.10 \\
\hline & \multirow{3}{*}{10} & 0.5 & 2.51 & 2.03 & 1.26 & 8.45 & 8.60 & 8.00 \\
\hline & & 1 & 2.21 & 1.54 & 1.04 & 8.30 & 8.56 & 8.70 \\
\hline & & 2 & 4.30 & 3.52 & 3.01 & 8.45 & 8.60 & 8.00 \\
\hline \multirow{12}{*}{ R2 } & \multirow{3}{*}{3} & 0.5 & 5.78 & 4.93 & 4.20 & 8.75 & 8.80 & 8.46 \\
\hline & & 1 & 5.34 & 4.03 & 3.58 & 8.75 & 8.80 & 9.41 \\
\hline & & 2 & 4.37 & 4.03 & 3.88 & 8.45 & 8.60 & 9.21 \\
\hline & \multirow{3}{*}{5} & 0.5 & 4.03 & 3.88 & 3.44 & 8.45 & 8.60 & 8.26 \\
\hline & & 1 & 3.72 & 2.50 & 1.89 & 8.75 & 8.80 & 9.41 \\
\hline & & 2 & 4.20 & 3.17 & 3.72 & 8.45 & 8.60 & 9.21 \\
\hline & \multirow{3}{*}{7.5} & 0.5 & 4.37 & 4.03 & 3.44 & 8.56 & 8.50 & 8.16 \\
\hline & & 1 & 2.21 & 1.89 & 1.17 & 7.83 & 8.20 & 8.81 \\
\hline & & 2 & 4.73 & 3.44 & 2.60 & 8.25 & 8.70 & 9.31 \\
\hline & \multirow{3}{*}{10} & 0.5 & 4.93 & 3.58 & 2.40 & 8.45 & 8.60 & 8.26 \\
\hline & & 1 & 2.21 & 1.54 & 1.04 & 8.30 & 8.56 & 9.17 \\
\hline & & 2 & 4.20 & 2.70 & 2.40 & 8.45 & 8.60 & 9.21 \\
\hline \multirow{4}{*}{ R3 } & \multirow{3}{*}{3} & 0.5 & 4.75 & 4.05 & 3.45 & 8.41 & 7.95 & 7.61 \\
\hline & & 1 & 4.35 & 3.30 & 2.98 & 9.36 & 7.95 & 8.56 \\
\hline & & 2 & 3.58 & 3.32 & 3.20 & 9.06 & 8.00 & 8.61 \\
\hline & 5 & 0.5 & 3.36 & 3.20 & 2.84 & 8.11 & 8.00 & 7.66 \\
\hline
\end{tabular}




\begin{tabular}{cccccccc} 
& 1 & 3.05 & 2.05 & 1.56 & 9.36 & 9.70 & 10.31 \\
& 2 & 3.45 & 2.60 & 3.10 & 9.06 & 8.00 & 8.61 \\
\hline \multirow{3}{*}{7.5} & 0.5 & 3.58 & 3.32 & 2.81 & 8.22 & 8.10 & 7.76 \\
& 1 & 1.81 & 1.55 & 1.05 & 8.44 & 8.40 & 9.01 \\
& 2 & 3.95 & 2.82 & 2.13 & 8.86 & 8.00 & 8.61 \\
\hline \multirow{3}{*}{10} & 0.5 & 4.03 & 2.91 & 1.94 & 8.11 & 8.00 & 7.66 \\
& 1 & 1.81 & 1.28 & 1.10 & 8.91 & 8.70 & 9.31 \\
& 2 & 3.45 & 2.23 & 1.97 & 9.06 & 8.00 & 8.61 \\
\hline
\end{tabular}
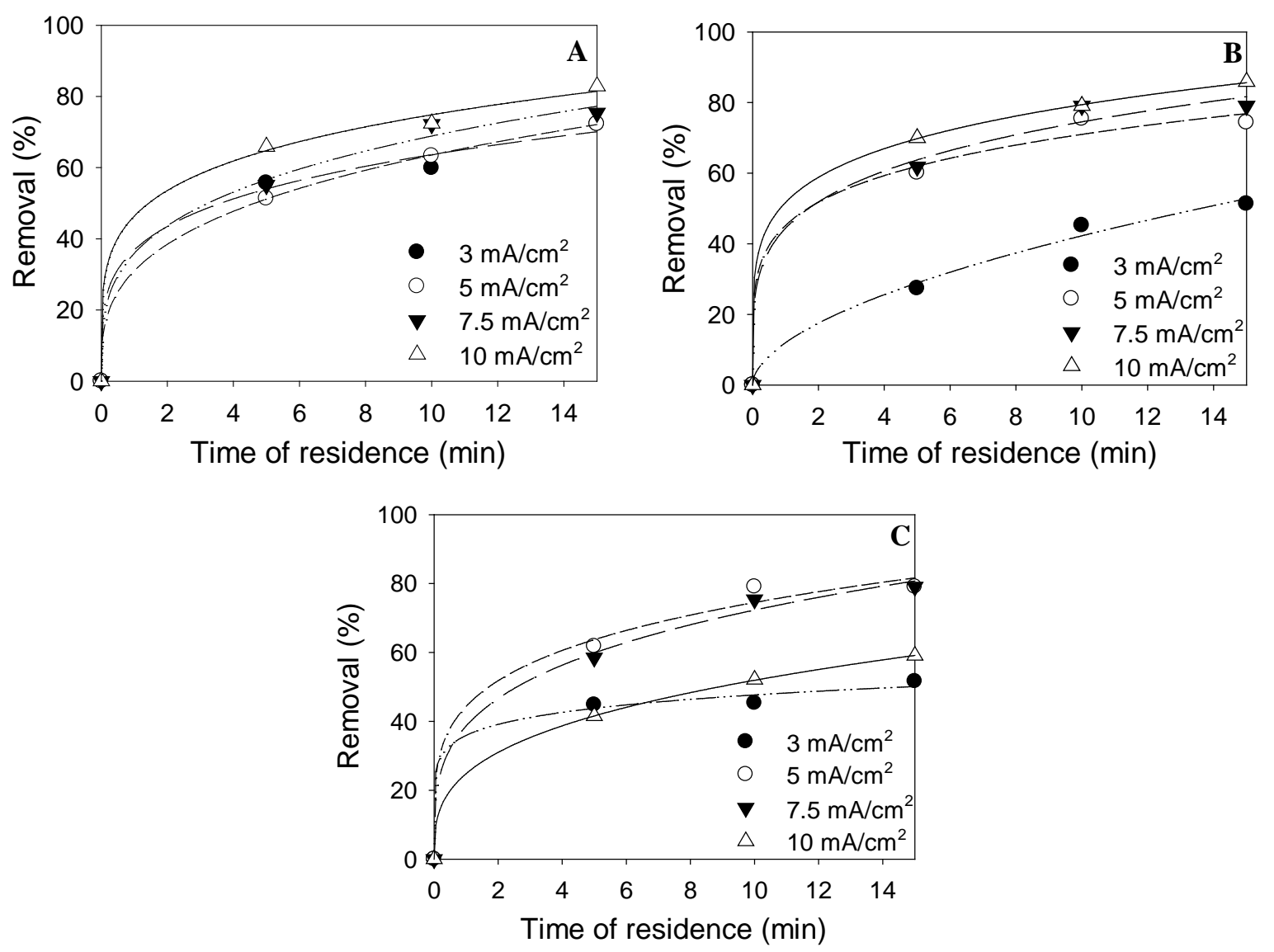

Figure 4. Fluoride removal percentage versus residence time for batch operation in reactor R1 for various current densities as indicated in the plots. Potential reversal period: A) 0.5, B) 1, and C) 2 $\min$.

In this case, similar results were obtained for residence times of 10 and 15 min for the former current density, while for $7.5 \mathrm{~mA} / \mathrm{cm}^{2}$ density the threshold level was only obtained for an operation time of $15 \mathrm{~min}$. 
In principle, an increase in the elimination of fluorides coupled with the increase in current density could be expected [40]. The current density determines the amount of $\mathrm{Al}^{3+}$ ions released from the electrodes and the amount of formed coagulants and, it affects the growth of $\mathrm{Al}(\mathrm{OH})_{3}$ flocs in the $\mathrm{EC}$ reactor. The coagulant $\mathrm{Al}(\mathrm{OH})_{3}(\mathrm{~s})$ is responsible for the removal of fluoride from the effluent, because these ions get adsorbed on the colloidal particles, eventually yielding larger flocs. When the current density increased, the removal yield also increased due to the production of more $\mathrm{Al}(\mathrm{OH})_{3}$, although for current densities higher than $12 \mathrm{~mA} / \mathrm{cm}^{2}$ the removal yield barely increased [41].

But, such a trend was only observed for the tests carried out using polarity change time of $1 \mathrm{~min}$. In this case, this removal trend was maintained in the tests carried out with a residence time of $15 \mathrm{~min}$, whereas for the $10 \mathrm{~min}$ tests the elimination data were almost the same for 3 and 5 $\mathrm{mA} / \mathrm{cm}^{2}$. On the other hand, for a residence time of $5 \mathrm{~min}$, elimination rates were higher using 3 rather than $5 \mathrm{~mA} / \mathrm{cm}^{2}$ current density. In addition, it was found that the removal percentage was affected by the duration of the potential reversal operation, producing higher fluoride removal percentages using $1 \mathrm{~min}$ of period of potential reversal compared to 0.5 and $2 \mathrm{~min}$.

An evolution in the amount of eliminated fluoride in accordance to expectations was observed for polarity reversal periods of 2 minutes, except for current densities of $10 \mathrm{~mA} / \mathrm{cm}^{2}$. In this case, the percentage of removed fluoride was slightly higher than that observed for current densities of $3 \mathrm{~mA} / \mathrm{cm}^{2}$ (slightly higher than $50 \%$ ). This may be due to the fact that with longer polarity change periods, a certain degree of passivation of the cathode can occur accompanied by an increase in the surface roughness of the electrode, thus effectively reducing the amount of effective current transferred between the anode and the cathode. This would imply a deviation from the theoretical behavior and a reduction in reactor efficiency [28,42-44].

The same potential increasing trend could be observed in all cases regarding the evolution of fluoride removal with increasing residence times $\left(t_{N}\right)$. The recorded temporal changes fit well with the predictions of the VOK model for all the current densities and half-periods of polarity change considered, a fact that was confirmed by the observation of $R^{2}$ values greater than 0.99 .

\subsection{Reactor of $368 \mathrm{~mL}$}

The next step in the scale-up consisted of a reactor of $368 \mathrm{~mL}$ capacity that contained 6 aluminum plates in parallel arrangement and bipolar electrode operation. The electrocoagulation 
method was still performed under a batch condition using this intermediate pilot reactor. Although the same experimental conditions were applied as in the case of the 2-electrode arrangement of the smaller reactor R1, an inspection of the results given in Figure 5 and Table 3 clearly evidence one major feature directly associated with the reactor scale-up process. Namely, fluoride removal values in excess of $80 \%$ were recorded only in the case of a polarity change period of $1 \mathrm{~min}$.

More precisely, only the experiments performed using current densities 7.5 and $10 \mathrm{~mA} / \mathrm{cm}^{2}$ produced fluoride removal equal or greater than $80 \%$, and these values were achieved for longer operation times, namely 10 and $15 \mathrm{~min}$. On the other hand, both shorter (0.5 min) and longer (2 min) polarity change periods delivered significantly less efficient fluoride removal, mostly in the order of $40-50 \%$, with the highest at $67 \%$ for a current density of $10 \mathrm{~mA} / \mathrm{cm}^{2}, 2 \mathrm{~min}$ polarity change period and 15 min operation time.
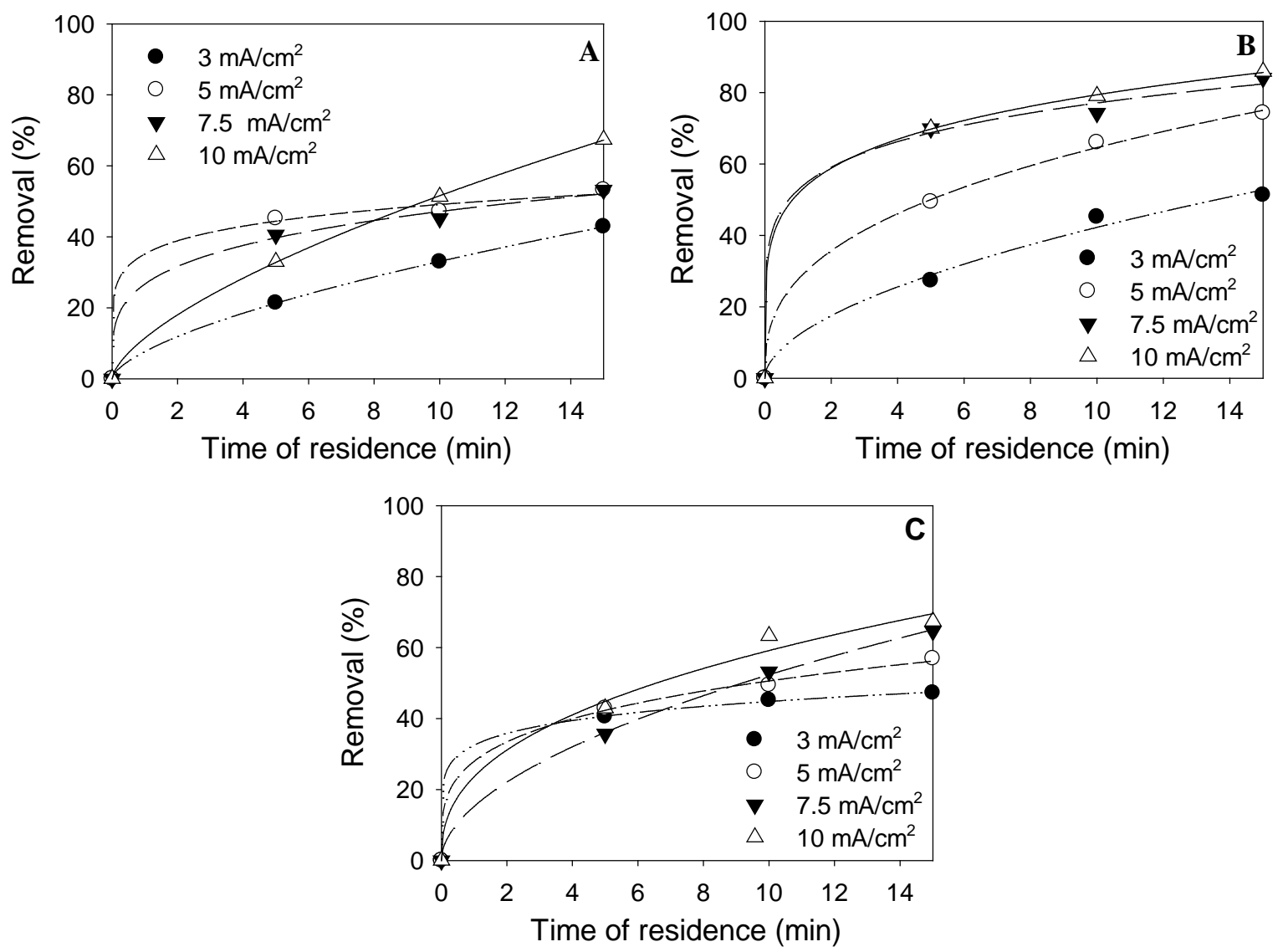

Figure 5. Fluoride removal percentage versus residence time for batch operation in reactor R2 for various current densities as indicated in the plots. Potential reversal period: A) 0.5, B) 1, and C) 2 $\min$. 
The smaller fluoride removal percentages observed using a potential reversal period of 2 minutes can be attributed to a passivation of the electrode as in the previous case, thus effectively rendering a decrease in floc formation. This feature implies a lower fluoride removal ratio for all the current densities tested. The values obtained were equal or slightly lower than those found for the previous reactor due to a lower turbulence in the reactor (the agitation system was the same although for a greater volume and a larger set of electrodes).

For a given period of potential reversal, increased fluoride removal was found to correlate directly with the increase in residence time. Furthermore, increased fluoride removal also occurred within each quartet of values by applying higher current densities in the electrochemical process.

\subsection{Reactor of $2000 \mathrm{~mL}$}

A $2000 \mathrm{~mL}$ capacity reactor was employed in the last step of our pilot reactor scale-up process. The design of the electrochemical cell allowed the system to be operated in both batch and continuous-flow tests.

\subsubsection{Batch operation}

For the sake of comparative purposes, the electrocoagulation process in the $2000 \mathrm{~mL}$ capacity reactor was first operated under batch conditions, and the operation results are shown in Figure 6 and Table 3. In general, the observed behavior is analogous to that found with the 368 $\mathrm{mL}$ reactor. Fluoride removal percentages higher than $80 \%$ were only accomplished using a polarity change period of $1 \mathrm{~min}$. In this case, almost an overlap occurs between the elimination rates achieved with current densities of 7.5 and $10 \mathrm{~mA} / \mathrm{cm}^{2}$.

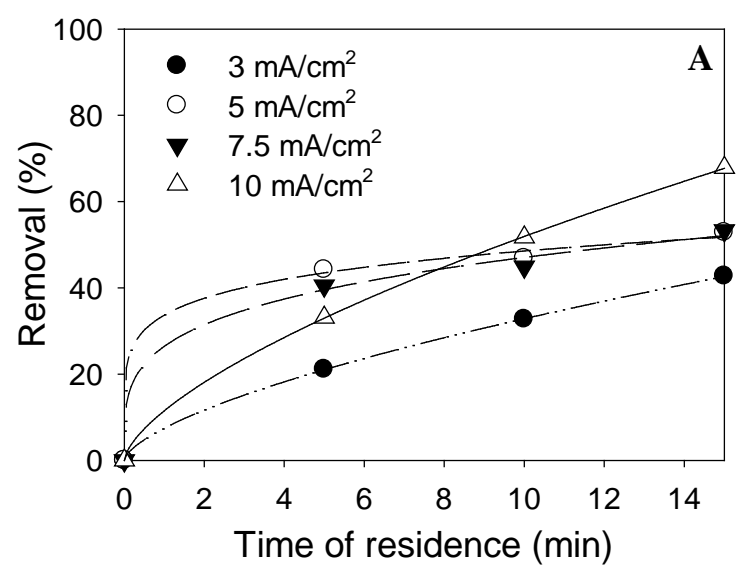



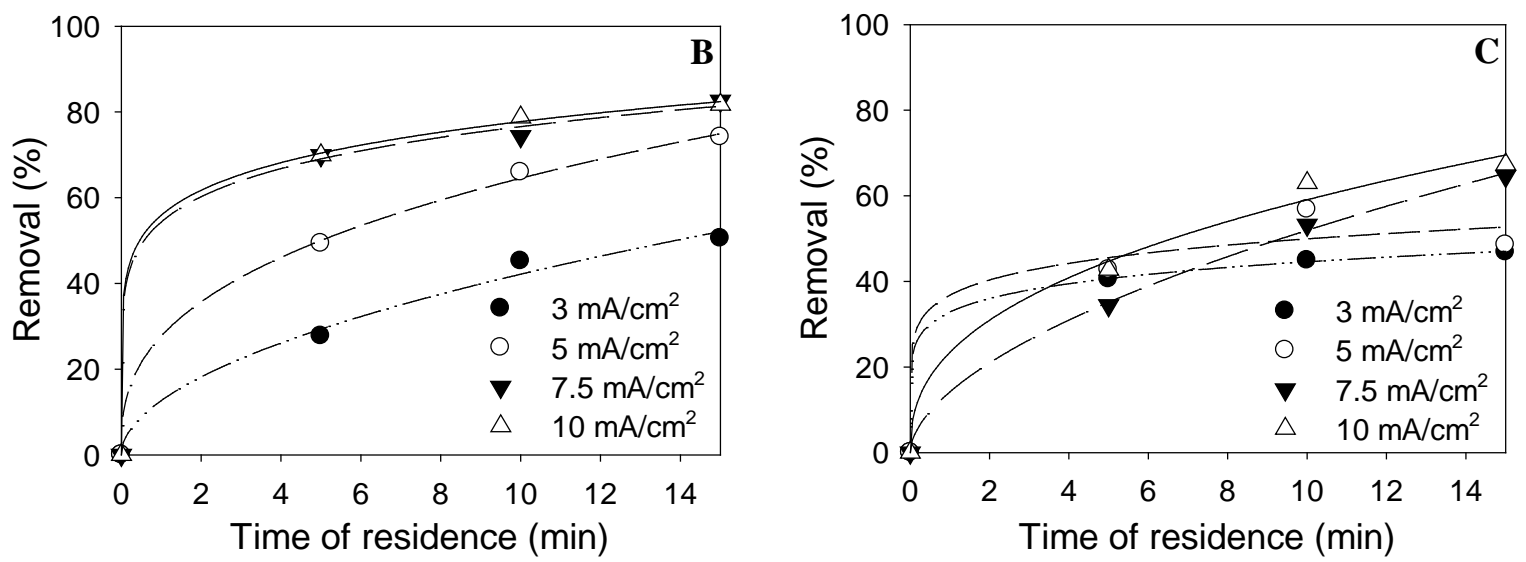

Figure 6. Fluoride removal percentage versus residence time for batch operation in reactor R3 for various current densities as indicated in the plots. Potential reversal period: A) 0.5, B) 1, and C) 2 min.

On the other hand, the tests carried out with the other two potential reversal periods of 0.5 and 2 min deliver fairly dispersed results among the data sets of the four current densities tested when they are compared for a given residence time. For the tests using the shortest period, the typical power-function behavior is apparently followed for residence times of 10 and 15 min, whereas the expected trend is only observed for an operation time of $15 \mathrm{~min}$ in the case of the longest potential reversal period. However, the maximum fluoride removal values do not exceed $70 \%$ even in these limiting potential reversal periods. The justification for this behavior is the same that was proposed to describe the observations in the smaller reactors R1 and R2.

\subsubsection{Continuous-flow cell operation}

Continuous-flow cell operation (with volumetric flow rate $20 \mathrm{~L} / \mathrm{h}$ ) was performed during $24 \mathrm{~h}$ in the $2000 \mathrm{~mL}$ reactor for three different current densities, namely 5, 7.5 and $10 \mathrm{~mA} / \mathrm{cm}^{2}$. Figure 7 depicts the performance of the EC system in terms of the fluoride removal percentage of the product water. In all cases, a constant fluoride concentration in the product water is reached after 20 min of operation. An 8.5 percentage unit difference was observed for the fluoride removal when operating between the lowest and highest current density values, leading to a final fluoride content of $1.4 \mathrm{mg} / \mathrm{L}$.

Table 4 shows the final results obtained for fluoride content, $\mathrm{pH}$, energy expenditure and operating costs calculated per one cubic meter of product water over a complete 24-hour continuous operation. The final fluoride content of the treated water remained within the limits 
allowed by current legislation in the experiments performed using current densities of 7.5 and 10 $\mathrm{mA} / \mathrm{cm}^{2}$, while it exceeded the established limit by $0.7 \mathrm{mg} / \mathrm{L}$ in the case of operation at $5 \mathrm{~mA} / \mathrm{cm}^{2}$. The $\mathrm{pH}$ did not vary with the applied current densities, maintaining a fairly stable value throughout the electrocoagulation operation, as well as in the three cases studied.

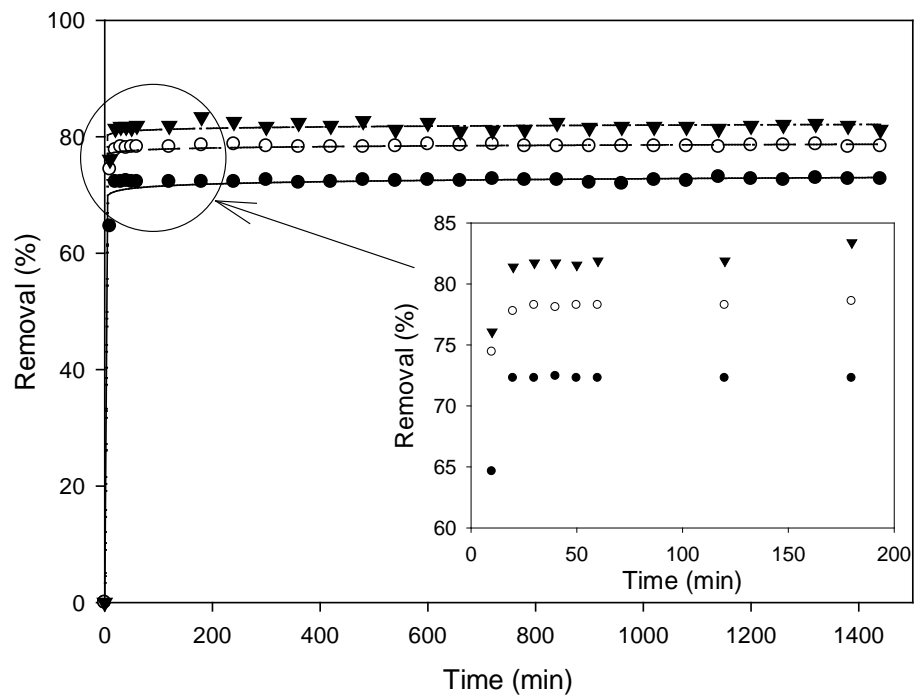

Figure 7. Fluoride removal percentage versus residence time for continuous flow operation in reactor R3 for various current densities: $(\bullet) 5,(O) 7.5$, and $(\boldsymbol{\nabla}) 10 \mathrm{~mA} / \mathrm{cm}^{2}$.

Table 4. Performance of the reactor R3 under continuous-flow operation during $24 \mathrm{~h}$.

\begin{tabular}{|c|c|c|c|c|c|}
\hline $\begin{array}{l}\text { Current density } \\
\qquad\left(\mathrm{mA} / \mathrm{cm}^{2}\right)\end{array}$ & $\begin{array}{c}{\left[\mathrm{F}^{-}\right]_{\mathrm{i}}} \\
(\mathrm{mg} / \mathrm{L})\end{array}$ & $\begin{array}{c}{\left[\mathrm{F}^{-}\right]_{\mathrm{f}}} \\
(\mathrm{mg} / \mathrm{L})\end{array}$ & $\mathrm{pH}_{\mathrm{f}}$ & $\begin{array}{c}\text { Energy expenditure } \\
\left(\mathbf{k W h} / \mathbf{m}^{3}\right)\end{array}$ & $\begin{array}{c}\text { Operation cost } \\
\left(€ / \mathbf{m}^{3} \text { product water) }\right.\end{array}$ \\
\hline 5 & & 2.20 & 8.2 & 0.92 & 0.12 \\
\hline 7.5 & 7.35 & 1.50 & 8.2 & 1.45 & 0.18 \\
\hline 10 & & 1.40 & 8.2 & 1.95 & 0.26 \\
\hline
\end{tabular}

The energy expenditure is directly related to the current density used, with an increase in the calculated energy expenditure associated with the increase in current density. Operating costs have been calculated taking into account the market prices of aluminum and electric power in Spain. These costs also reflect an increase in relation to the increase in the current density supplied. 
When considering the two operating conditions that produce water in compliance with the legislation in terms of the final fluoride content, there is a difference of $0.08 € / \mathrm{m}^{3}$ of treated water between them, which implies a considerable extra cost from one case to another in order to maintain a margin of safety in the amount of fluoride present in the product water. However, this would allow waters to be treated with a higher initial concentration of the contaminant.

By fitting the experimental data of Figure 7 to pseudo-first order kinetics, we obtain that the kinetic constant is of the same order of magnitude regardless of the current density applied to the system. A value of $6.41 \times 10^{-2} \mathrm{~min}^{-1}$ is obtained for a current density of $5 \mathrm{~mA} / \mathrm{cm}^{2}, 7.51 \times 10^{-2}$ $\mathrm{min}^{-1}$ for a current density of $7.5 \mathrm{~mA} / \mathrm{cm}^{2}$, and $8.41 \times 10^{-2} \mathrm{~min}^{-1}$ for a current density of $10 \mathrm{~mA} / \mathrm{cm}^{2}$, which agrees well with the results reported by $\mathrm{Hu}$ et al. [31] using synthetic waters. On the other hand, when adjusting the results obtained to the VOK model [31], the theoretical residence time, $t_{N}$, was calculated based on equation (5):

$$
t_{N}=\frac{Z \cdot F \cdot V}{\varepsilon_{\mathrm{Al}} \cdot \varepsilon_{C} \cdot n \cdot \dot{1} \cdot \Gamma_{\max }} \cdot\left[\left(\left[\mathrm{F}^{-}\right]_{\mathrm{i}}\left[\mathrm{F}^{-}\right]_{\mathrm{f}}\right)+\frac{1}{k} \cdot \ln \left(\frac{\left[\mathrm{F}^{-}\right]_{\mathrm{i}}}{\left[\mathrm{F}^{-}\right]_{\mathrm{f}}}\right)\right]
$$

This equation is similar to that obtained by Mameri et al. [29], who estimated $t_{N}$ from equation (6):

$$
t_{N}=\frac{B}{i}
$$

where $i$ is the current density. By combining equations (5) and (6), an expression is derived for the calculation of $B$, as reflected in equation (7): residence time, $t_{N}$, was calculated based on equation (5):

$$
t_{N}=\frac{Z \cdot F \cdot V}{\varepsilon_{\mathrm{Al}} \cdot \varepsilon_{C} \cdot n \cdot A \cdot \Gamma_{\max }} \cdot\left[\left(\left[\mathrm{F}^{-}\right]_{\mathrm{i}}-\left[\mathrm{F}^{-}\right]_{\mathrm{f}}\right)+\frac{1}{k} \cdot \ln \left(\frac{\left[\mathrm{F}^{-}\right]_{\mathrm{i}}}{\left[\mathrm{F}^{-}\right]_{\mathrm{f}}}\right)\right]
$$

where $A$ is the area of the electrodes.

In addition, equation (7) can be employed to determine the theoretical residence time according to this model. To do this, it has been considered that the joint efficiency $\left(\varepsilon_{\mathrm{Al}} \varepsilon \mathrm{C}\right)$ was $120 \%$ because the current efficiency, $\varepsilon$ c, is usually higher than $100 \%$ due to the simultaneous dissolution of the anodes and the cathodes in the bipolar operation [31]. In fact, the actual value of this parameter must be obtained experimentally. Other parameters in equation (7) are: the number of cells $n$, 7 for the $2000 \mathrm{~mL}$ reactor; $Z$ is 3 for aluminum; $F$ is the Faraday constant $(96485 \mathrm{C} / \mathrm{mol})$; $V$ is the volume of the reactor, $2 \mathrm{~L}$; $\Gamma_{\max }$ and $k$ adopt the values of 0.474 and $1520 \mathrm{M}^{-1}$ respectively 
[45]; and the area of electrodes is $4.06 \times 10^{-2} \mathrm{~m}^{2}$. As a result, we obtain a value of $B=772.41$. For the estimated optimal current density, the residence time obtained according to the VOK model is 8.2 minutes, $45 \%$ less than the approximate experimental finding of $15 \mathrm{~min}$. The difference between experimental and fitted values can be attributed to the assumptions made. As we decrease the current density, the data supplied by the model fit closer to the experimental results. Thus, for a current density of $7.5 \mathrm{~mA} / \mathrm{cm}^{2}$, the predicted theoretical $t_{N}$ is $10.6 \mathrm{~min}$, whereas it becomes 14.8 min for a current density of $5 \mathrm{~mA} / \mathrm{cm}^{2}$.

\subsection{Sludge characterization}

The coagulant employed to remove fluoride ions from the effluent was formed during the EC process by metal dissolution, eventually yielding larger flocs and finally, sludge. The sludge was removed from the system by filtration process and dried at room temperature. Once dried, it was characterized by the Zeta potential analysis leading to the plot shown in Figure 8. A delivering value of zero was employed to assist adequate selection of the process to be employed for the separation of the two phases existing in the flocculation tank. The results obtained show that the sludge produced can be effectively separated by atmospheric filtration.

Chemical characterization of the dried sludge was performed using XRD. The XRD diffractogram in Figure 9 shows peaks corresponding to fixed fluoride-containing aluminum oxyhydroxide and aluminum hydroxide. The presence of those compounds confirm the effective absorption of fluoride in solution by the aluminum hydroxide formed during the EC process.

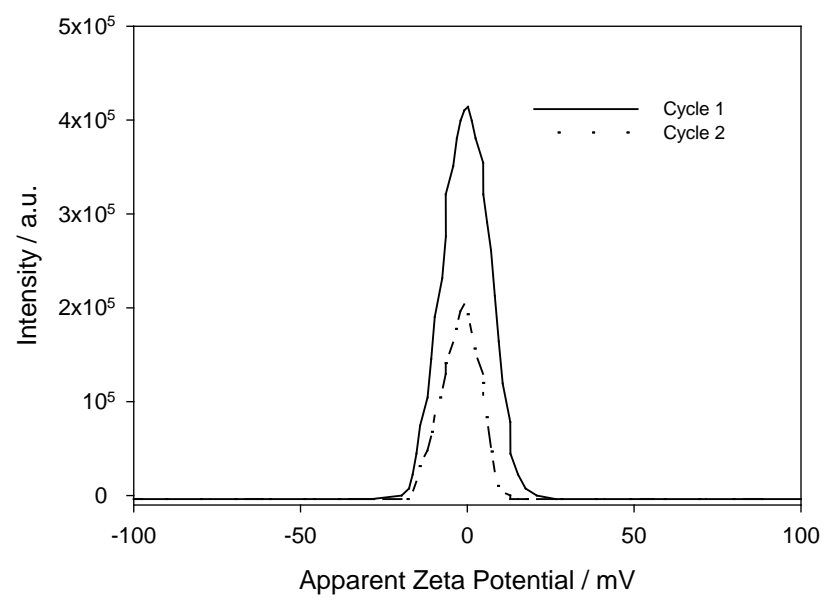

Figure 8. Zeta potential distribution of the solid phase from the sludge obtained by atmospheric filtration after dried at room temperature. 


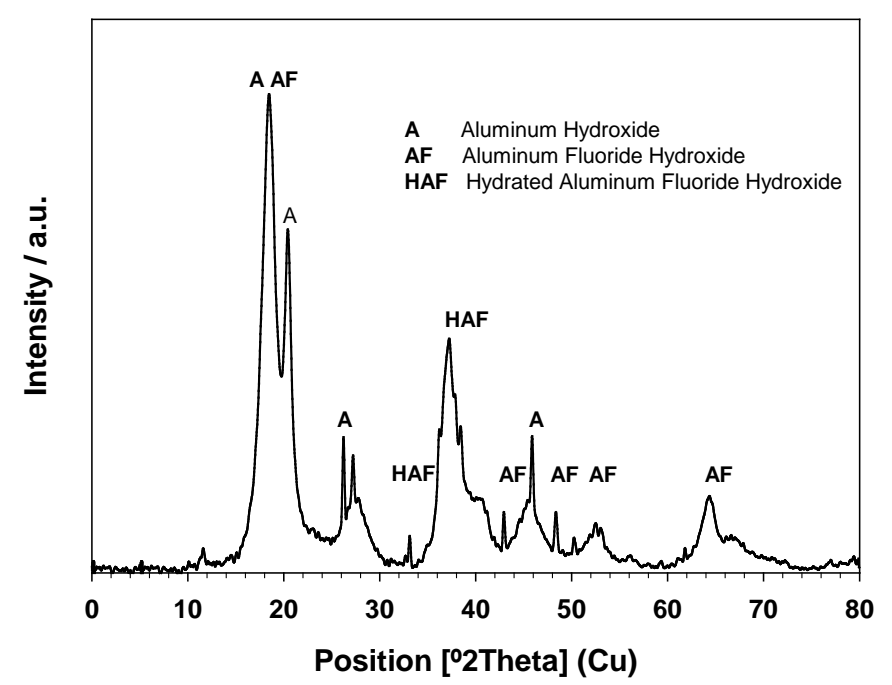

Figure 9. X-ray diffractograms of the sludge after drying the filtered sludge during $24 \mathrm{~h}$ at room temperature.

\section{Conclusions}

It has been shown that fluoride mitigation for water from underground natural sources can be achieved by an electrocoagulation technique using a bipolar cell arrangement of aluminum electrodes operating under continuous flow conditions. That is, it is possible to satisfy the requirements of the current legislation on water for human consumption, provided the appropriate operating conditions are optimized considering the composition of the water supply.

The optimized operating conditions in the EC cell, namely residence time equal to $15 \mathrm{~min}$ and current density $10 \mathrm{~mA} / \mathrm{cm}^{2}$, produce the highest fluoride removal percentage of $85.9 \%$ with respect to feed water with total fluoride ion content equal to $7.35 \mathrm{mg} / \mathrm{L}$, leading to product water with the lowest total fluoride concentration of $1.04 \mathrm{mg} / \mathrm{L}$.

The set of tests performed for each proposed reactor, respond to the same trend in the percentage of fluoride removal, when referring to the same basic operating conditions. In all the tests carried out, the same potential increasing trend in the evolution of fluoride removal was observed as the residence time increased, according to the predictions of the VOK model. The theoretical estimates of the residence time derived from the application of the VOK model present values close to those obtained experimentally for the various current densities investigated in this work. 
The analysis of the dried sludge confirm the effective absorption of fluoride ion by the aluminum hydroxide formed during the EC process.

\section{Acknowledgements}

Financial support by the Comunidad de Aguas Barranco de Vergara (Los Realejos, Spain) under research contract "Estudio de viabilidad a escala de laboratorio del tratamiento de aguas subterráneas fluoradas por electrocoagulación” is gratefully acknowledged. V.F.M. is grateful to the University of La Laguna and Obra Social “La Caixa” for a research contract.

\section{References}

1. D. Kanduti, P. Sterbenk, B. Artnik, Fluoride: A review of use and effects on health, Mater Sociomed. 28 (2016) 133-137. https://doi.org/10.5455/msm.2016.28.133-137.

2. D. Ozsvath, Fluoride and environmental health: A review, Rev. Environ. Sci. Bio. 8 (1) (2008) 59-79. https://doi.org/10.1007/s11157-008-9136-9.

3. World Health Organization, Guidelines for Drinking-water Quality, 4th edn., World Health Organization, Geneva, 2011.

4. Gobierno de España, Real Decreto 140/2003, de 7 de febrero, por el que se establecen los criterios sanitarios de la calidad del agua de consumo humano. BOE núm. 45, de 21/02/2003. (2003).

5. Directiva 98/83/CE del Consejo, de 3 de noviembre de 1998, relativa a la calidad de las aguas destinadas al consumo humano, DOUE 330 (1998).

6. E. Custodio, M.C. Cabrera, R. Poncela, L.-O.Puga, E. Skupien, A. del Villar, Groundwater intensive exploitation and mining in Gran Canaria and Tenerife, Canary Islands, Spain: Hydrogeological, environmental, economic and social aspects, Sci. Total Environ. 557-558 (2016) 425-437. https://doi.org/10.1016/j.scitotenv.2016.03.038.

7. W. D’Alessandro, Human fluorosis related to volcanic activity: A review, Environmental Toxicology, WIT Transactions on Biomedicine and Health 10 (2006) 21-30. https://doi.org/10.2495/ETOX060031.

8. S. Ayoob, A.K. Gupta, Fluoride in drinking water: A review on the status and stress effects, Crit. Rev. Env. Sci. Tec. 36 (2006) 433-487. https://doi.org/10.1080/10643380600678112. 
9. A. Bhatnagar, E. Kumar, M. Sillanpää, Fluoride removal from water by adsorption - A review, Chem. Eng. J. 171 (2011) 811-840. https://doi.org/10.1016/j.cej.2011.05.028.

10. E.W. Wambu, W.O. Ambusso, C.O. Gerald, K. Muthakia, Review of fluoride removal from water by adsorption using soil adsorbents - An evaluation of the status, J. Water Reuse Desal. 6 (2016) 1-29. https://doi.org/10.2166/wrd.2015.073.

11. P. Praipipat, M.M. El-Moselhy, K. Khuanmar, P. Weerayutsil, T.T. Nguyen, S. Padungthon, Enhanced defluoridation using reusable strong acid cation exchangers in $\mathrm{Al}^{3+}$ form (SAC-Al) containing hydrated Al(III) oxide nanoparticles, Chem. Eng. J. 314 (2017) 192-201. https://doi.org/10.1016/j.cej.2016.12.122.

12. S.V. Jadhav, E. Bringas, G.D. Yadav, V.K. Rathod, I. Ortiz, K.V. Marathe, Arsenic and fluoride contaminated groundwaters: A review of current technologies for contaminants $\begin{array}{lllll}\text { removal, } & \text { J. } & \text { Environ. } & \text { Manage. } & 162\end{array}$ (2015) 306-325. https://doi.org/10.1016/j.jenvman.2015.07.020.

13. M.I. Litter, M.E. Morgada, J. Bundschuh, Possible treatments for arsenic removal in Latin American waters for human consumption, Environ. Pollut. 158 (2010) 1105-1118. https://doi.org/10.1016/j.envpol.2010.01.028.

14. M. Tahaikt, I. Achary, M.A. Menkouchi Sahli, Z. Amor, M. Taky, A. Alami, A. Boughriba, M. Hafsi, A. Elmidaoui, Defluoridation of Moroccan groundwater by electrodialysis: Continuous operation, Desalination $189 \quad$ 215-220. https://doi.org/10.1016/j.desal.2005.06.027.

15. Z. Amor, B. Bariou, N. Mameri, M. Taky, S. Nicolas, A. Elmidaoui, Fluoride removal from brackish water by electrodialysis, Desalination $133 \quad$ (2001) 215-223. https://doi.org/10.1016/S0011-9164(01)00102-3.

16. J. Sadhwani Alonso, L. Álvarez Álvarez, N. Melián-Martel, J. Sadhwani Díaz, The Canary Islands and its passion for water desalination, Desalin. Water Treat. 55 (2015) 2340-2350. https://doi.org/10.1080/19443994.2014.939862.

17. P.I. Omwene, M. Kobya, O.T. Can, Phosphorus removal from domestic wastewater in electrocoagulation reactor using aluminium and iron plate hybrid anodes, Ecol. Eng. 123 (2018) 65-73. https://doi.org/10.1016/j.ecoleng.2018.08.025. 
18. M.M. Emamjomeh, M. Sivakumar, Review of pollutants removed by electrocoagulation and electrocoagulation/flotation processes, J. Environ. Manage. 90 (2009) 1663-1679. https://doi.org/10.1016/j.jenvman.2008.12.011.

19. L. Feng, E.D. van Hullebusch, M.A. Rodrigo, G. Esposito, M.A. Oturan, Removal of residual anti-inflammatory and analgesic pharmaceuticals from aqueous systems by electrochemical advanced oxidation processes. A review, Chem. Eng. J. 228 (2013) 944-964. https://doi.org/10.1016/j.cej.2013.05.061.

20. P. Cañizares, C. Jiménez, F. Martínez, C. Sáez, M. A. Rodrigo, Study of the electrocoagulation process using aluminum and iron electrodes, Ind. Eng. Chem. Res. 46 (2007) 6189-6195. https://doi.org/10.1021/ie070059f.

21. M.A. Mamelkina, S. Cotillas, E. Lacasa, C. Sáez, R. Tuunila, M. Silanpää, A. Häkkinen, M.A. Rodrigo, Removal of sulfate from mining waters by electrocoagulation, Sep. Purif. Technol. 182 (2017) 87-93. http://dx.doi.org/10.1016/j.seppur.2017.03.044.

22. S. Vasudevan, M.A. Oturan, Electrochemistry: As cause and cure in water pollution-an overview, Environ. Chem. Lett. 12 (2014) 97-108. https://doi.org/10.1007/s10311-013-0434$\underline{2}$.

23. V. Khandegar, A.K. Saroha, Electrocoagulation for the treatment of textile industry effluent - A review, J. Environ. Manage. $128 \quad$ (2013) 949-963. https://doi.org/10.1016/j.jenvman.2013.06.043.

24. P. Song, Z. Yang, G. Zeng, X. Yang, H. Xu, L. Wang, R. Xu, W. Xiong, K. Ahmad, Electrocoagulation treatment of arsenic in wastewaters: A comprehensive review, Chem. Eng. J. 317 (2017) 707-725. https://doi.org/10.1016/j.cej.2017.02.086.

25. J. Llanos, S. Cotillas, P. Cañizares, M.A. Rodrigo, Electrocoagulation as a key technique in the integrated urban water cycle - A case study in the centre of Spain, Urban Water J. 14 (2017) 650-654. http://dx.doi.org/10.1080/1573062X.2016.1223322.

26. S. Pulkka, M. Martikainen, A. Bhatnagar, M. Sillanpää, Electrochemical methods for the removal of anionic contaminants from water - A review, Sep. Purif. Technol. 132 (2014) 252271. http://dx.doi.org/10.1016/j.seppur.2014.05.021.

27. G. Chen, Electrochemical technologies in wastewater treatment, Sep. Purif. Technol. 38 (2004) 11-41. https://doi.org/10.1016/j.seppur.2003.10.006. 
28. M.Y.A. Mollah, P. Morkovsky, J.A. Gomes, M. Kesmez, J. Parga, D.L. Cocke, Fundamentals, present and future perspectives of electrocoagulation, J. Hazard. Mater. 114 (2004) 199-210. https://doi.org/10.1016/j.jhazmat.2004.08.009.

29. N. Mameri, A.R. Yeddou, H. Lounici, D. Belhocine, H. Grib, B. Bariou, Defluoridation of septentrional Sahara water of North Africa by electrocoagulation process using bipolar aluminium electrodes, Water Res. 32 (1998) 1604-1612. https://doi.org/10.1016/S00431354(97)00357-6.

30. M.M. Emamjomeh, M. Sivakumar, An empirical model for defluoridation by batch monopolar electrocoagulation/flotation (ECF) process, J. Hazard. Mater. 131 (2006) 118-125. https://doi.org/10.1016/j.jhazmat.2005.09.030.

31. C.-Y. Hu, S.-L. Lo, W.-H. Kuan, Simulation the kinetics of fluoride removal by electrocoagulation (EC) process using aluminum electrodes, J. Hazard. Mater. 145 (2007) 180-185. https://doi.org/10.1016/j.jhazmat.2006.11.010.

32. M.M. Emamjomeh, M. Sivakumar, Fluoride removal by a continuous flow electrocoagulation $\begin{array}{lllll}\text { reactor, } & \text { J. } & \text { Environ. } & \text { Manage. } & 90 \quad \text { (2009) }\end{array}$ https://doi.org/10.1016/j.jenvman.2008.06.001.

33. J. Zhu, H. Zhao, J. Ni, Fluoride distribution in electrocoagulation defluoridation process, Sep. Purif. Technol. 56 (2007) 184-191. https://doi.org/10.1016/j.seppur.2007.01.030.

34. A. Hardisson, M.I. Rodríguez, A. Burgos, L. Díaz Flores, R. Gutiérrez, H. Várela, Fluoride levels in publicly supplied and bottled drinking water in the Island of Tenerife, Spain, Bull. Environ. Contam. Toxicol. 67 (2001) 163-170. https://doi.org/10.1007/s001280106.

35. ASTM, ASTM G1-03(2017), Standard Practice for Preparing, Cleaning and Evaluating Corrosion Test Specimens, ASTM, Materials Park, OH, 2017.

36. D. Ghosh, C.R Medhi, M.K. Purkait, Techno-economic analysis for the electrocoagulation of fluoride-contaminated drinking water, Toxicol. Environ. Chem. 93 (2011) 424-437. https://doi.org/10.1080/02772248.2010.542158.

37. T. Kim, C. Park, E. Shin, S. Kim, Decolorization of disperse and reactive dyes by continuous electrocoagulation process, Desalination 150 (2002) 165-175. https://doi.org/10.1016/S00119164(02)00941-4. 
38. C.Y. Hu, S.L. Lo, W.H. Kuan, Y.D. Lee, Removal of fluoride from semiconductor wastewater by electrocoagulation-flotation, Water Res. $39 \quad$ (2005) 895-901. https://doi.org/10.1016/j.watres.2004.11.034.

39. C.Y. Hu, S.L. Lo, W.H. Kuan, Y. De Lee, Treatment of high fluoride-content wastewater by continuous electrocoagulation-flotation system with bipolar aluminum electrodes, Sep. Purif. Technol. 60 (2008) 1-5. https://doi.org/10.1016/j.seppur.2007.07.040.

40. M. Changmai, M. Pasawan, M.K. Purkait, A hybrid method for the removal of fluoride from drinking water: Parametric study and cost estimation, Sep. Purif. Technol. 206 (2018) 140148. https://doi.org/10.1016/j.seppur.2018.05.061.

41. M. Alimohammadi, A. Mesdaghinia, M. H. Shayesteh, H. J. Mansoorian, N. Khanjani, The efficiency of the electrocoagulation process in reducing fluoride: application of inductive alternating current and polarity inverter, Int. J. Environ. Sci. Technol. (2019) 1-16 https://doi.org/10.1007/s13762-019-02297-4

42. M. Eyvaz, M. Kirlaroglu, T. S. Aktas and E. Yuksel, The effects of alternating current electrocoagulation on dye removal from aqueous solutions, Chem. Eng. J. 153 (2009) 16-22. (2009). https://doi.org/10.1016/j.cej.2009.05.028.

43. K.L. Dubrawski, C. Du, M. Mohseni, General potential-current model and validation for $\begin{array}{lllll}\text { electrocoagulation, } & \text { Electrochim. } & \text { Acta } & 129 \quad \text { (2014) }\end{array}$ http://dx.doi.org/10.1016/j.electacta.2014.02.089.

44. A. Guzmán, J.L. Nava, O. Coreño, I. Rodríguez, S. Gutiérrez, Arsenic and fluoride removal from groundwater by electrocoagulation using a continuous filter-press reactor, Chemosphere 144 (2016) 2113-3120. https://dx.doi.org/10.1016/j.chemosphere.2015.10.108. 